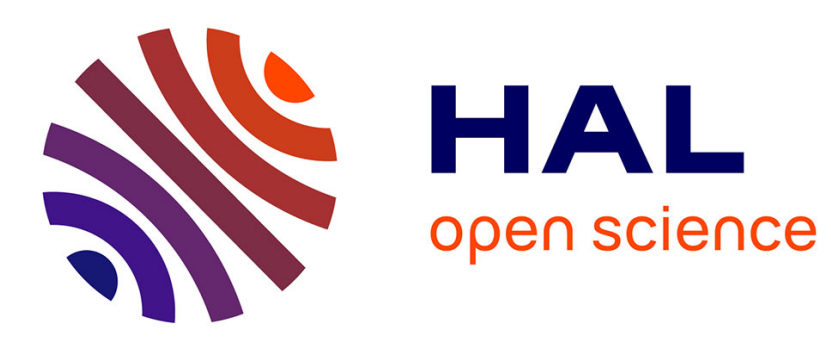

\title{
The Impact of regulatory capital regulation on balance sheet structure, intermediation cost and growth
}

Pierre-Charles Pradier, Hamza El Khalloufi

\section{To cite this version:}

Pierre-Charles Pradier, Hamza El Khalloufi. The Impact of regulatory capital regulation on balance sheet structure, intermediation cost and growth. 2016. halshs-01390915

\section{HAL Id: halshs-01390915 \\ https://shs.hal.science/halshs-01390915}

Submitted on 2 Nov 2016

HAL is a multi-disciplinary open access archive for the deposit and dissemination of scientific research documents, whether they are published or not. The documents may come from teaching and research institutions in France or abroad, or from public or private research centers.
L'archive ouverte pluridisciplinaire HAL, est destinée au dépôt et à la diffusion de documents scientifiques de niveau recherche, publiés ou non, émanant des établissements d'enseignement et de recherche français ou étrangers, des laboratoires publics ou privés. 


\section{Documents de Travail du \\ PANTHEON SORBONNE Centre d'Economie de la Sorbonne}

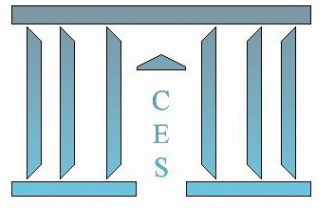

The Impact of regulatory capital regulation on balance sheet structure, intermediation cost and growth

Pierre-Charles PRADIER, Hamza El KHALlOUfi

2016.61

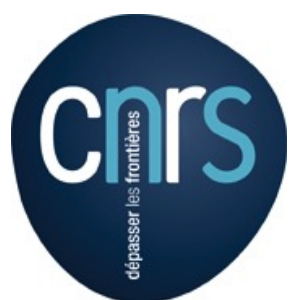




\title{
The Impact of regulatory capital regulation on balance sheet structure, intermediation cost and growth
}

\author{
Pierre-Charles Pradier ${ }^{\mathrm{I}}$ \\ Université Paris I Panthéon-Sorbonne \\ Centre d'Economie de la Sorbonne et LabEx RéFi
}

\author{
Hamza El Khalloufi \\ Université Paris I Panthéon-Sorbonne \\ PRISM et LabEx RéFi
}

While support for strengthening financial regulation was unanimous after the financial crisis (with the customary exception of both radical groups and financial lobbies $^{2}$ ), there have been recently some notable breaches in the consensus. Prominent European politicians have publicly expressed the idea that a break was needed to complete an overall assessment of past work (EP 20I6), "remove unnecessary burden" and cut red tape (Brunsden 20I5), while some took a more aggressive stance in front of their domestic audience: Emmanuel Macron (20I6) and Gianfelice Rocca (Sanderson 20I6) have been vocal against excessive financial regulation, which would have become a burden for corporations, and might be responsible for the enduring recession in the European Union. The same argue that US and emerging countries quickly recovered after the 2007 financial crisis and resumed growth in 2 years at most, so they enjoyed a full business cycle before experiencing the current slowdown. On the contrary, Europe has experienced a protracted financial crisis, with commercial banks failures and fragilities not yet resolved as recent developments in Portugal (Wise 20I6) and Italy (Hale 20I6) have proven. At the same time, the economy has been growing slowly or negatively in the during the last years, especially in the Eurozone: fiscal consolidation and banking sector balance sheet unwinding had an obvious negative macroeconomic impact. With the economic policy offering some relief, as an EU-centered scheme (the Juncker Plan) opened opportunities for removing targeted government expenses from deficit constraints, and ECB flooded the markets with cheap money and promises to continue, one should have expected the beginning of business cycle to rely on credit. Loans to corporations notwithstanding failed to improve as graph s shows, and GDP growth stayed weaker than before the crisis.

\footnotetext{
1 We wish to thank Jean-Paul Laurent and Nuno Coimbra for their advice and comments. All errors remain ours.

2 Such as the Institute of International Finance, see IIF (2010), (2011).
} 
Figure 1 - GDP and amount outstanding of loans to NFC in the Eurozone, Em

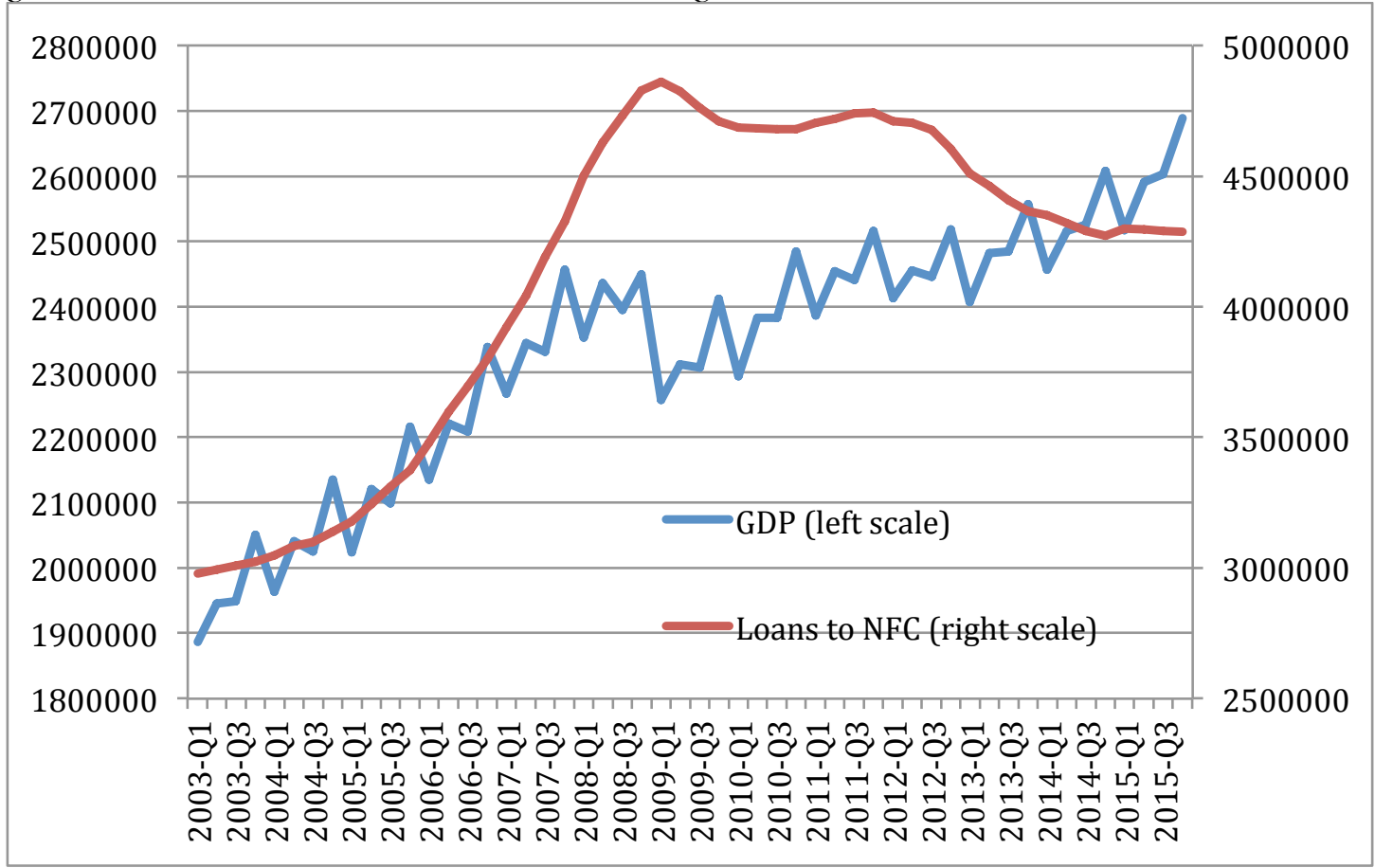

source: ECB statistical datawarehouse

The situation is especially worrying for SME, which account for $67 \%$ of EU employment (in Non-Financial Corporations) since "SME bank lending has suffered a significant backdrop in volumes, from a peak of EUR 95 billion in mid-20o8 to approximately EUR 54 billion in 20I3/20I/" (EBA 20I6b p. 8). SME are especially reliant on bank credit (through overdraft or loans) since they enjoy limited access to other financing options available to larger corporations (figure 2 from EBA $2016 \mathrm{~b}$ p. I9), especially from securitisation, which is low in Europe in comparison with the US see the next chapter by Daphné Héant et al.).

Figure 2 - Access to funding sources $2015 \mathrm{H} 2$ in \% of firms

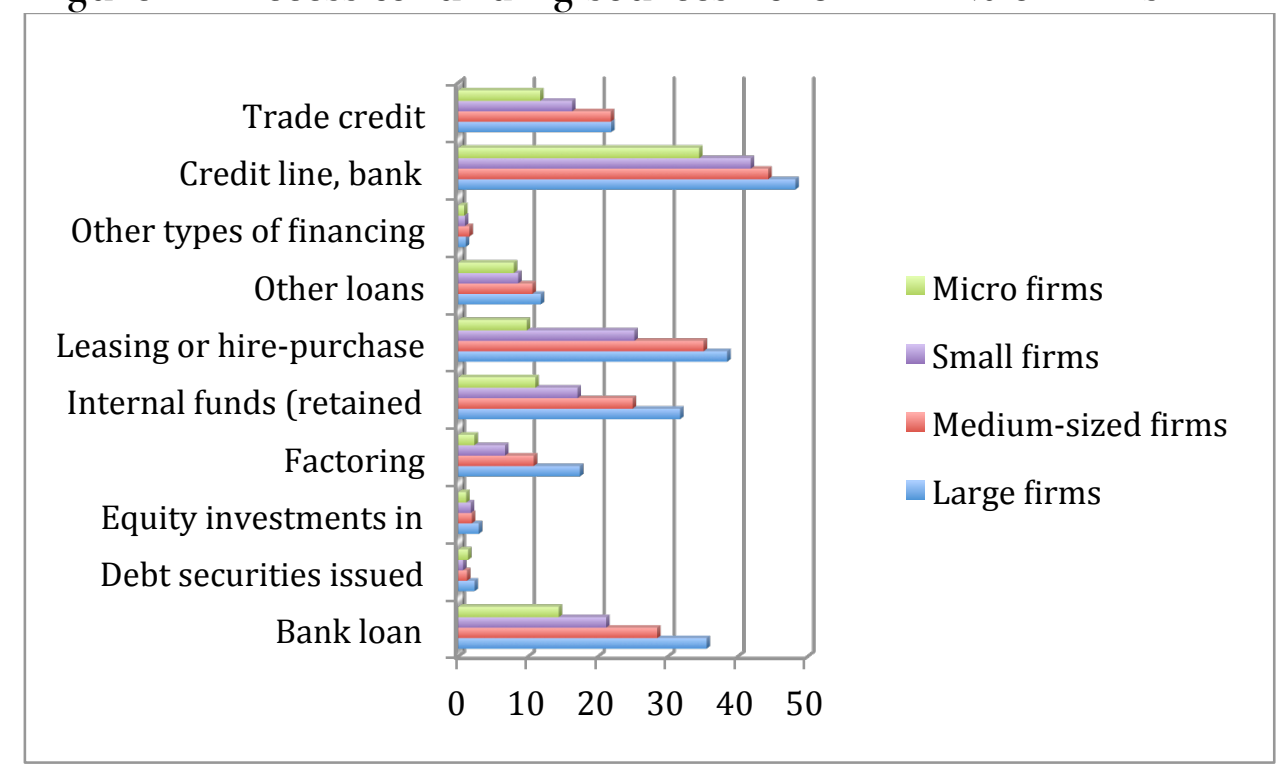

source: ECB statistical datawarehouse 
As conventional and unconventional economic policy tools seems to have exhausted their virtue, one can then ask whether the overall tightening of bank regulation is not responsible for the current state of low growth and missing foregone business cycle through declining credit to corporations, especially to the smaller ones.

In order to answer this question, one must maybe look at the currently implemented or announced measures, which imposed new costs to financial institutions, these costs being eventually paid by the customer. But the expected developments might also matter: banks might be reacting to the expected future regulation, and the credit tightening might be the result of uncertainty aversion in a context of uncertain public policies. It would be thus difficult to assess the steady state impact of any regulatory measure. Moreover, nonconventional monetary policies are distorting the usual economic signals: first, negative interest rates on deposits with the European central bank plus repeated QE operations have driven short terms returns so low that investors and banks together have lost their usual points of reference in the risk/return space. In the case of banks, many observers believe their economic model is being deeply challenged by both the flatness of yield curve (return on maturity transformation) and the low level of interest rates (return on deposits). Conversely, current regulation might be interpreted as a mild constraint: the single resolution mechanism, for instance, is designed to organize bail-in and rescue troubled banks without the influx of taxpayer money, but the whole scheme is just a tentative 'credible threat' since nobody really expects, in the current European economic environment, that governments will let any large bank get bankrupt, endangering the whole economy. Hence implicit government support still biases the risk/return arbitrage in a way, which is difficult to determine. Given these 3 problems (I. Convergence is not steady state, 2. QE displaces and distorts the yield curve, 3. Changing implicit government support), it seems especially difficult to understand how the new Basel III metrics changes the Basel II-adjusted risk/return filtering, transforming the asset-side structure of banks' balance sheets.

While it seem difficult to answer such a complex problem, we will try to disentangle the effect of every set of causes, taking into account expected future rules. The rest of this chapter is organized as follows: we will first recall the main novelties of the Basel III package as implemented in the UE (I.) before we turn to impact assessments (2.), trying to answer the question: what definite constraint is binding at the moment? (3.) Eventually section (4.) will offer some remediation before concluding.

\section{Novelties of Basel III (CRD IV/CRR) and their anticipated effects on lending}

The European implementation of the Basel III package (through CRD IV and CRR) aims at "[strengthening] the resilience of the EU banking sector so it would be better placed to absorb economic shocks while ensuring that banks continue to finance economic activity and growth" (EC 2013), especially in Europe where banks are the main financing actors (Schackmann-Falli-Weiss 20I4). Among the novelties of the Basel III regulatory package, the most significant in terms of impact on corporate lending practices are likely to be capital requirements (I.I.), overall leverage (I.2.), and liquidity ratios (I.3.). Let us review them in this order. 


\subsection{Capital requirements}

Basel III increased the capital requirements in order to strengthen the banks at a microprudential level: table I describes the increase in overall quantity, but the capital quality is also enhanced and the risk weighted assets (RWA) computation rules are stiffened so that overall the amount of required capital for a given balance sheet has been raised (see Jean-Paul Laurent's contribution in this volume, section 2). The table also features the systemic risk surcharge imposed by the Financial Stability Board, which has still to be passed in European law.

Table 1 - regulatory capital requirements: Basel II vs. Basel III

\begin{tabular}{|c|c|c|c|}
\hline & $\begin{array}{c}\text { Basel II reqd cap } \\
\text { \%RWA }\end{array}$ & $\begin{array}{lll}\text { Basel III reqd } \\
\text { cap }\end{array}$ & $\begin{array}{l}\text { Authority in } \\
\text { charge }\end{array}$ \\
\hline $\begin{array}{l}\text { Common Equity } \\
\text { Tier I capital }\end{array}$ & $\cong 4$ & 4.5 & $\begin{array}{l}\text { ECB or National } \\
\text { Supervisor }(\mathbf{I})\end{array}$ \\
\hline $\begin{array}{l}\text { Additional Tier I } \\
\text { capital }\end{array}$ & $\mathrm{o}$ & I. 5 & $\begin{array}{l}\text { ECB or National } \\
\text { Supervisor }\end{array}$ \\
\hline Tier 2 capital & $\begin{array}{c}\mathrm{T}_{2}: \max 100 \% \text { of } \\
\mathrm{T}_{\mathrm{I}} \\
\text { T3: } \max 250 \% \text { of } \\
\text { market risk } \mathrm{T}_{\mathrm{I}}\end{array}$ & 2 & $\begin{array}{l}\text { ECB or National } \\
\text { Supervisor }\end{array}$ \\
\hline $\begin{array}{l}\text { Capital } \\
\text { conservation } \\
\text { buffer }\end{array}$ & o & 2.5 & $\begin{array}{l}\text { ECB or National } \\
\text { Supervisor }\end{array}$ \\
\hline $\begin{array}{l}\text { Partial sum } \\
\text { (basic capital) }\end{array}$ & $8 \%$ & I0. 5 & Multiplier: г.3і \\
\hline $\begin{array}{l}\text { Countercyclical } \\
\text { buffer }\end{array}$ & o & $0-2.5$ & $\begin{array}{l}\text { National } \\
\text { Competent } \\
\text { Authority }\end{array}$ \\
\hline G-SIB Buffer & $\mathrm{O}$ & $0-5$ & $\begin{array}{l}\text { Financial } \\
\text { Stability Board }\end{array}$ \\
\hline D-SIB Buffer & $\mathrm{O}$ & $0-5$ & $\begin{array}{l}\text { National } \\
\text { Competent } \\
\text { Authority }\end{array}$ \\
\hline (Pillar 2 buffers) & o & $0-2$ & $\mathrm{ECB}$ \\
\hline TLAC & $8 \%$ & Іо, $5 \%-20 \%$ & $\begin{array}{l}\text { Multiplier: } \text { І.3І- } \\
2.5\end{array}$ \\
\hline
\end{tabular}

(i) ECB for ECB directly supervised banks ${ }^{3}$, National Supervisory Authorities for other financial institutions.

\footnotetext{
3 Since the 4th of November 2014, "significant" banks are directly supervised by the European Central Bank. According to Council Regulation (EU) No 1024/2013 art. 6, a bank is deemed significant if it fulfills at least one of the following conditions (1) The value of its assets exceeds $€ 30$ billion; (2.) The value of its assets exceeds both
} 
The table shows that the basic capital amount is only lightly impacted (I0.5\% instead of $8 \%$ ) but the Total Loss Absorption Capacity might be as high as $20 \%$ for banks with maximum systemic surcharge: this would commend a $15 \% \%$ increase over the Basel II framework. Recent reports have measured the actual increase in regulatory capital: from $5.5 \%$ to $12.5 \%$ between $2009 \mathrm{Q}_{\mathrm{I}}$ and $20 \mathrm{I} 4 \mathrm{Q} 4$ in the US (Tier I alone, Fed 2015 p. 2), from $4.9 \%$ to $12 \%$ in Eurozone between the December 2010 QIS and the EBA Monitoring Exercise of September 2015 (Group i banks ${ }^{4}$ only, Quignon 2016 p. 25). These are overall figures, though, and the specific provision of regulatory capital for business loans is not distinguished. It seems reasonable to conjecture that these provisions have increased in a slightly higher proportion, since corporate debt is in the higher bracket of capital requirement, especially in comparison with mortgage loans or EU sovereign bonds ${ }^{5}$.

At this point, we established a concomitance between increased capital requirements and decreasing loans to financial corporations. This is not a satisfying causal explanation, though, but a partial description of the Basel III framework implementation. Let us proceed to the other features of the same package.

\subsection{Overall leverage}

The Basel III framework requires the banks to have their capital equal to $3 \%$ at least of their balance sheet; this limit implies a maximum 33: leverage. While this is not directly binding for corporate lending, as the basic capital charge of ı.5\% imply a 9.5 :I leverage (which is often less as corporate loans can be charged above $100 \%$ of the basic requirements according to the borrower's creditworthiness), it might be indirectly binding. Banks listed in the US are required to apply a Supplementary Leverage Ratio of 5\%, or 6\% for IDR, Insured Depository Institutions. But US banks are far above this floor: the last published figure was $8.8 \%$ on average (Fed 2015 p. 3), with the only two banks in the sample missing the stress tests being US branches of European banks. For Group I European banks competing at a global level, it seems almost impossible to steadily display lower figures than their American counterparts, hence capital build-up might not be over. If we take in consideration the average US banks leverage as the "desired leverage", it might become a binding constraint as most assets carry a capital charge lower than corporate loans: the former might thus contribute to the saturation of the leverage constraint, effectively crowding out the later.

\subsection{Liquidity ratios}

Basel III features two liquidity ratios: a short term Liquidity Coverage Ratio (LCR) under progressive implementation in the EU and a longer term Net Stable Funding Ratio (NSFR) whose possible implementation remains to be decided.

$€ 5$ billion and $20 \%$ of the Gross Domestic Product of the member state in which it is located; further regulation added; (3.) The bank is among the three most significant banks of the country in which it is located; (4.) The bank has large cross-border activities and (5.) The bank receives, or has applied for, assistance from Eurozone bailout funds (the European Stability Mechanism or European Financial Stability Facility).

${ }^{4}$ Group 1 banks are banks with Tier 1 capital in excess of EUR 3 billion and internationally active. All other banks are categorised as Group 2 banks.

5 In the standardized risk approach, corporate debt must be backed by $20 \%$ (for AAA-rated borrowers) to $150 \%$ of the standard regulatory capital provision, while claims secured by residential property only need $35 \%$ of the standard provision and EU sovereign debt $0 \%$. 


\subsubsection{Short-term liquidity}

The LCR is defined as the ratio of the value of the stock of High Quality Liquid Assets (in stressed conditions) divided by net cash outflows over the next 3o calendar days. It is supposed to be above $70 \%$ in 2016 , with this constraint being stiffened in the coming years $(80 \%$ from I January 2017, and 100\% from I January 20I 8$)$. It is thus expected that LCR implementation will have a growing, effect on lending since loans are not liquid, hence they do not count in the numerator of the LCR. On the other hand, this effect is only indirect: only banks with an insufficient volume of liquid assets might be restricted from lending. For this reason, the European banking authority is minimizing the effect of LCR on bank lending behavior (EBA 20I4 p. 23). Is it any different for the long-term ratio?

\subsubsection{Long-term liquidity}

The NSFR is such that Available Stable Funding divided by Required Stable Funding on a one-year horizon should be above Ioo\%. These quantities may be computed using haircuts detailed in BCBS 20I4: ASF weighs liabilities for instance Tier I regulatory capital is weighted at $100 \%$ while deposits are weighted between $50 \%$ and $95 \%$ according to their stability) and RSF weighs assets (from o\% for coins and banknotes to $100 \%$ for assets encumbered for a period of one year or more). This being said, most performing corporate loans are weighted at 85\% (non-performing loans receiving a $100 \%$ weight). This means that bank must hold not only regulatory capital but also $85 \%$ of the amount lent as stable funding, for instance $85 \%$ of regulatory capital or $85: 0.9=94.44 \%$ on stable deposit accounts of the amount lent. This constraint would likely be binding for many banks, if only NSFR were due for implementation in the EU. At the moment there is no deadline for such plan, but the European Banking Authority is pushing for NSFR implementation (EBA 20I5).

The obvious conclusion of this first section is that lending to business is likely to be penalized by almost every aspect of the new regulatory package. This is leading us to the question of the overall effect of this package on economic growth via the firm-financing channel.

\section{Regulatory impact on financing businesses:}

In this section, we will distinguish between impact studies reliant on the interest-rate methodology (2.I.) from newer one, which were inspired by new theoretical developments (2.2.). The latter seem to better fit the current state of the EU economy but the former are still usually produced and cited, see $e . g$. Quginon (2016).

\subsection{Interest-rate reliant impact studies}

The earliest assessments of the Basel III package addressed an important causal chain: rising regulatory capital will raise the cost of borrowing leading to reduction in lending and ultimately to less output. Oliveira Santos, Elliott (2012) for instance, surveyed the early impact studies carried on by the regulators (BCBS) and the industry (IIF) (Table 2) 
Table 2

Table 1. Basel III Impact on Credit and GDP Growth

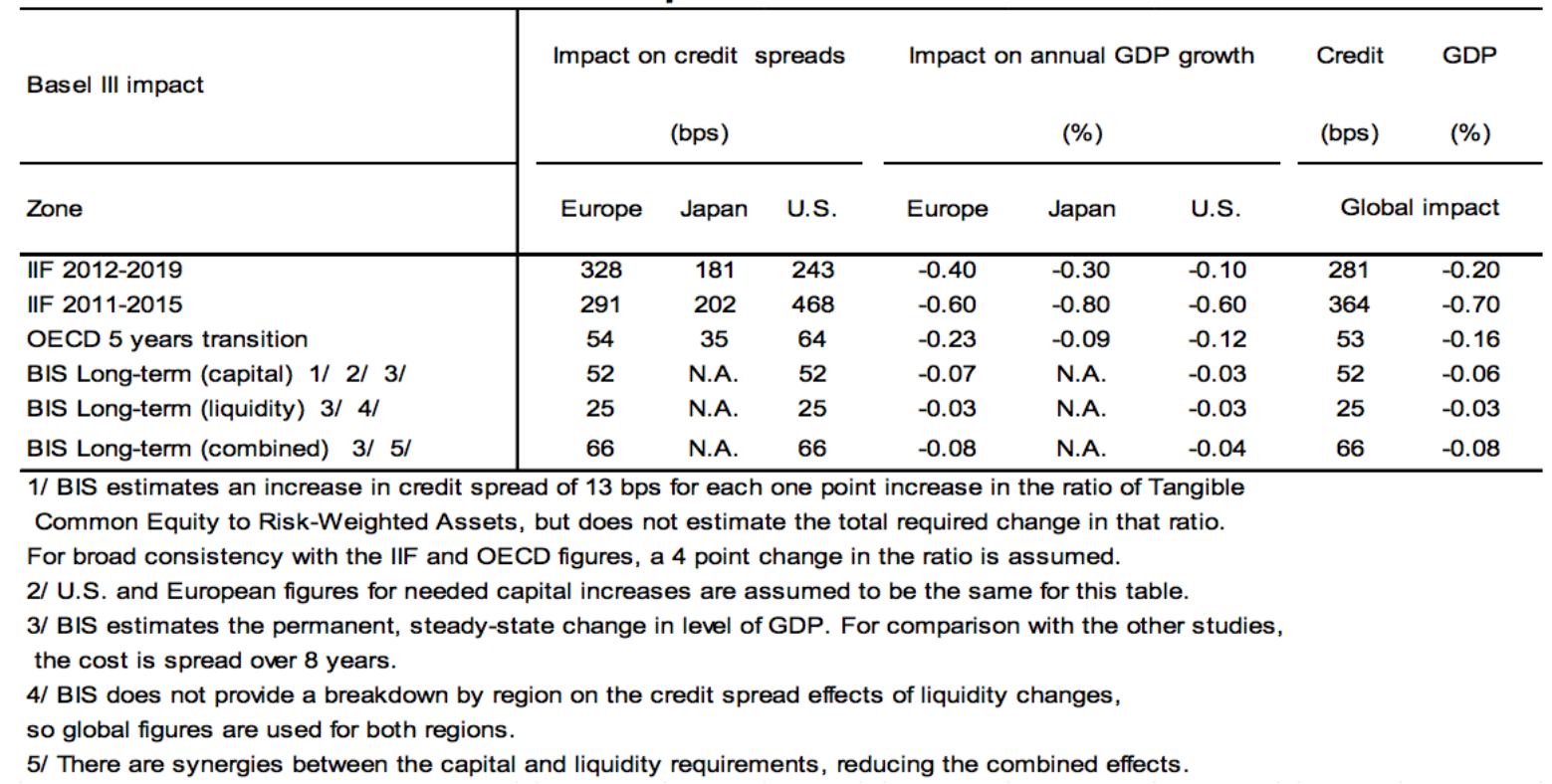

All these impact studies concluded that the additional capital requirements were likely to substantially raise the borrowing costs, leading to falling equilibrium lending with a definite impact on GDP. More recently, Quignon argued that the rise in regulatory capital $(+7 \%$ of RWA) was far higher than considered by BCBS 2010 assessments $(+\mathrm{I} .3 \%$ ), hence the consequences should be reassessed and the impact on growth would appear more significant.

The problem with all these studies is obvious since they rely on a transmission mechanism, which has been de-activated by the ECB monetary policy since the massive quantitative easing carried on under Mario Draghi's presidency. Figure 3 shows how the banks cost of lending sharply decreased after the $€_{4} 89 \mathrm{bn}$ package of December 2oII, the LTRO of February 2012 and the beginning of the QE in September 2012. Although the Joint Committee recently stated that the banks margins were "low $(. .$.$) in the context of a$ low interest rate environment" ( $\mathrm{JC} 2016$ p. 4), the borrowing costs could hardly be lower. Hence the negative effects pointed out by the aforementioned array of impact studies are likely to have disappeared with the current monetary policy. 
Figure 3 - Composite cost of bank deposit and bond financing
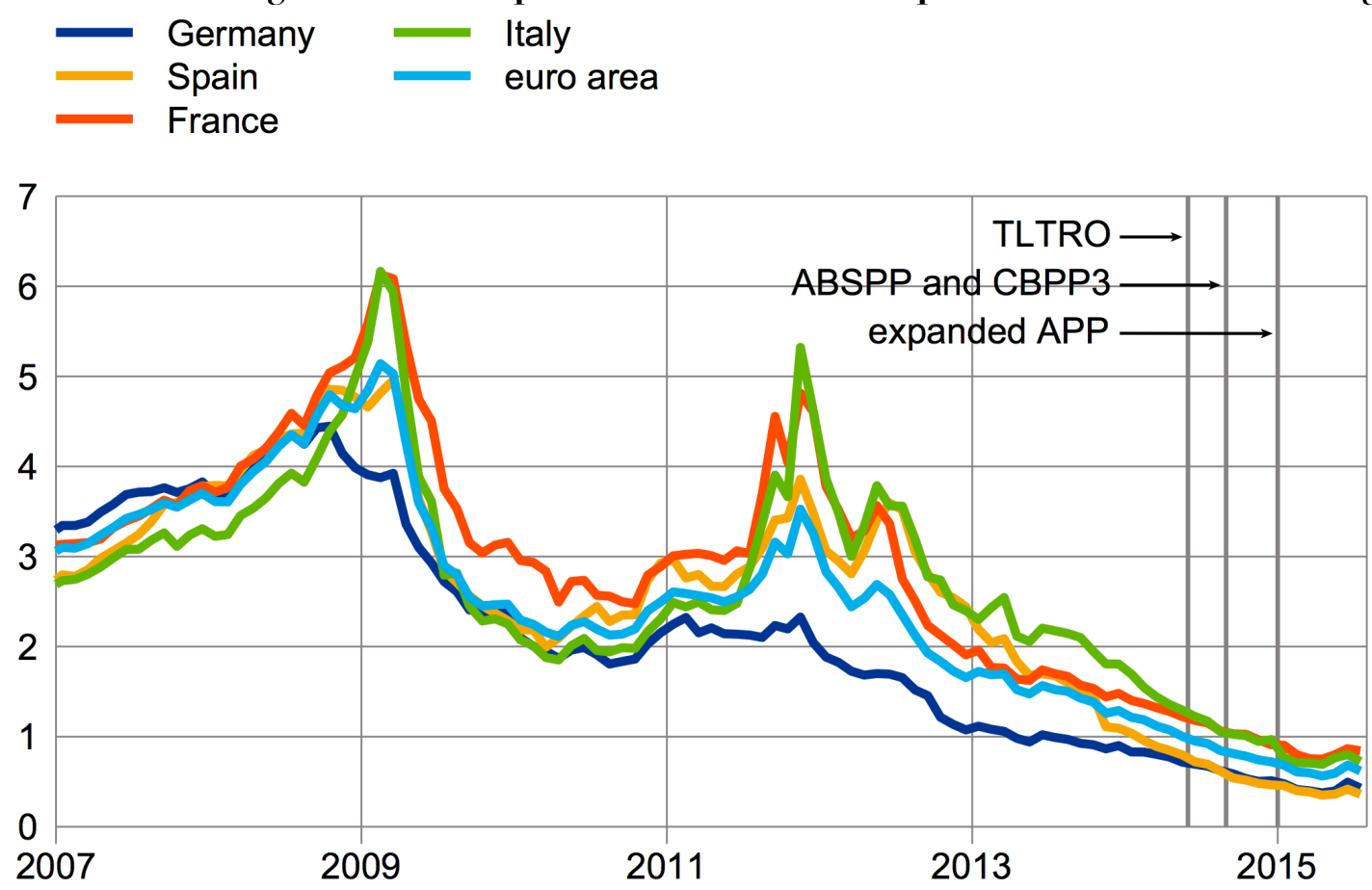

Sources: ECB 2015 p. 38 Notes: Average of deposit rates on new business and cost of market debt funding weighted with their corresponding outstanding amounts. Vertical lines denote the announcement dates of the respective measures. The latest observation is for July 2015.

One could still ask whether the impact studies were not pointing to substantial issues for the years 2009-2013, as the borrowing costs were still high and likely to be raised by the imminence of Basel III implementation. According to the ECB credit monitor data, it is likely that loan demand was depressed when the crisis broke out in 20o8-2oog then around 2012 (Figure 4). On the contrary, the net percentage of banks reporting positive loan demand from NFC was high during 2010 and 20II, and it began to rise again since $2012 \mathrm{Q} 4$, the growth of loans still being negative. It seems then that, while demand for loans from NFC has been low in the wake of the crisis, it is rising now since the beginning of QE, but the amount lent failed to pick up yet. It is then necessary to ask whether this failure is not the side effect of the Basel III package, as we have seen some reason to think it might be. New theoretical grounds have been given to assess the performance of the newly implemented reform. 
Figure 4: Changes in demand and amount growth for loans or credit lines to enterprises in EU (net percentages of banks reporting positive demand).

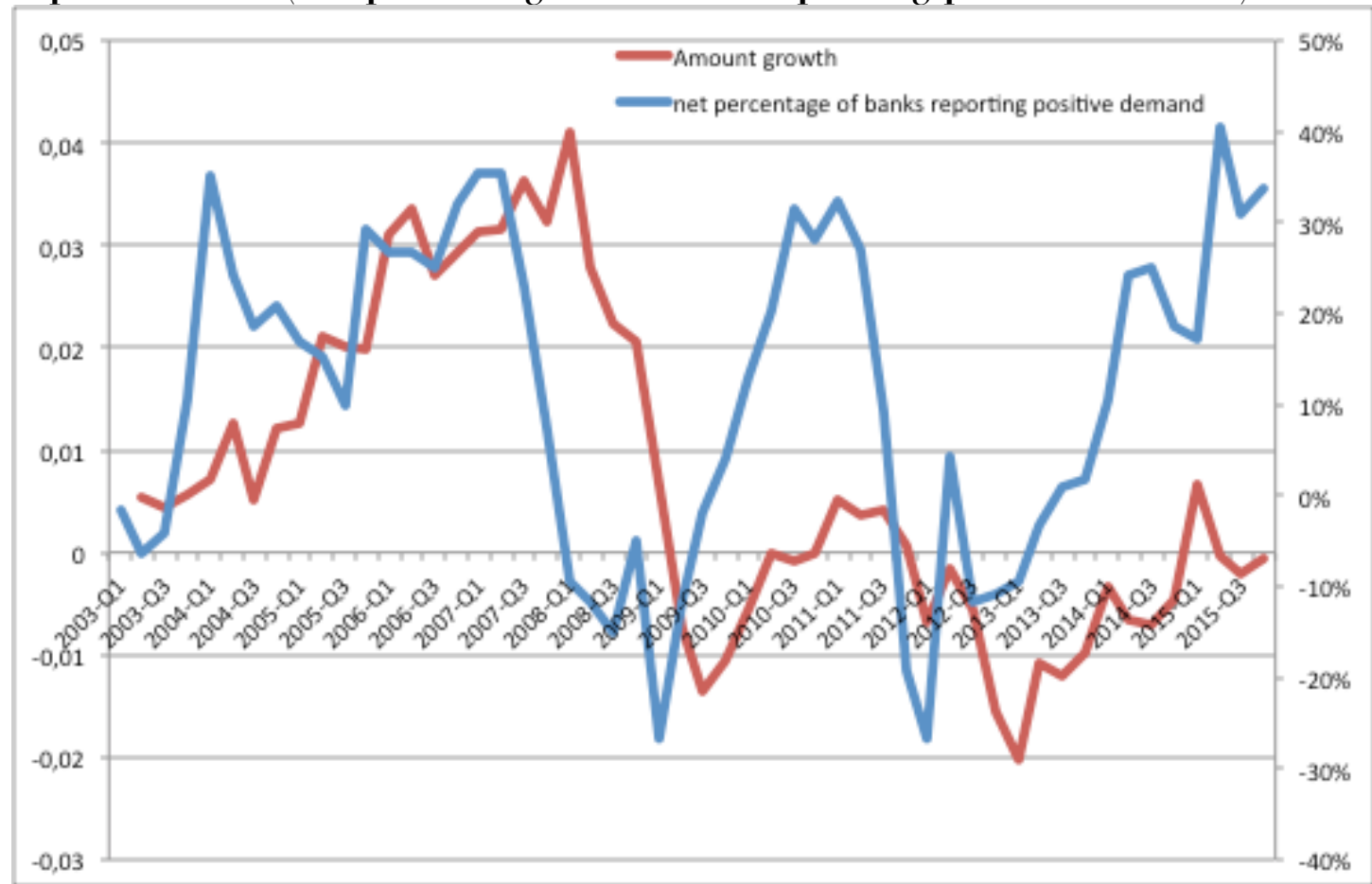

Source : ECB statistical datawarehouse

\subsection{New theoretical developments}

In 2008, Borio and Zhu issued a seminal contribution, first as BIS working paper republished as a Journal article in 2012. The title explicitly mentioned risk-taking as a transmission mechanism of monetary policy. It thus rationalized the idea that the impact of the Basel III package not only depended on interest rate. In particular, the paper discusses the difference between threshold effect in capital requirements which raises the borrowing cost, as already seen) and framework effect, which might twist asset allocation as some classes of assets might be favoured or incentivized by the overall framework while others would not. EU sovereign bonds, for instance, benefit from positive framework effect, and it shall be asked whether corporate loans were not negatively affected by the framework effect.

The question was given a more general scope with the development of the risk-taking channel concept, which inaugurated a huge literature, involving both theoretical and empirical research. Basically, the risk-taking channel is a possible new channel of monetary policy, which leads investors to invest more, when interest rate fall, than investment function of interest rate would have predicted. Three convergent effects are at work with the risk-taking channel:

- "One set of effects operates through the impact of interest rates on valuations, incomes and cash flows." This is the idea behind the real balance effect of Pigou (I943) or financial accelerator (Bernanke et al., I999), allowing for "time-varying risk aversion...", which makes it even more procyclical than the former. In this respect, lowering interest rate through monetary policy not only make investors richer, hence more willing to spend and invest all things being equal; they might 
also experience a drop in their risk aversion leading to even higher spending and investment.

- "A second set of effects operates through the relationship between market rates and target rates of return" This is to say that institutions linked by a sticky rate (life insurance companies with a contractual rate of return, for instance) might experience a margin squeeze with relaxed monetary policy: these institutions then engage in search for yield, which lead to select riskier assets.

- "A third set of effects operates through the communication policies and reaction function of the central bank. (...) By increasing the degree of transparency or commitment accompanying specific moves, and hence removing uncertainty about the future, the central bank can compress risk premia - a "transparency effect", adding an extra kick to the effect of those moves." This is more or less the theoretical rationalization of new communication policies such as forward guidance.

The paper triggered a tidal wave of empirical research, for instance Antipa-Matheron (2014) established with a dynamic stochastic general equilibrium model calibrated to euro area data that forward guidance is very effective at the 'zero lower bound' (= zero nominal discount rate), by providing a substantial boost to demand and reducing the costs of private deleveraging at the same time. The underlying mechanism relies on inflation announcement that create negative real interest rate expectations. In the Eurozone, though, the main financing operations rate has been below inflation since 20II, but ECB failed both to raise inflation enough to produce definitely negative real interest rates expectation, and to have the amount lent to NFC picking up with pre-crisis level. Overall, while QE is hopefully negating the impact of Basel III on interest rates, the risk-taking channel is not working as intended. We shall then ask, given the previously gathered evidence, which element of the reform package appears to act as binding constraint in lending to corporations?

\section{What is the binding constraint?}

Taking together unpalatable empirical facts (3.г.) with theoretical explanations for the mixed results of the Basel III implementation (3.2.) we try to offer a convincing narrative (3.3.).

\section{1. unpalatable empirical facts}

We would like to introduce at three categories of such facts.

\section{Measurement error}

A recent paper in ECB 2015 has shown that the previously issued statistics on amount lent were reporting optimistic figures in comparison with the new methodology implemented in September 20I5. While the difference appear (figure 5) small for NFC (one half of a growth point in 2015 and even less for the previous years) in comparison with households for instance (more than one point), the new methodology confirms that the amount outstanding of loans to NFC diminished for the 2012Q3-2015Q4 period, while banks were reporting increasing funding demand from the NFC. 
Figure 5: annual growth rate, seasonally adjusted - dotted line: pre-September 2015 methodology; solid line: post-September 2015 methodology

private sector

households

non-financial corporations

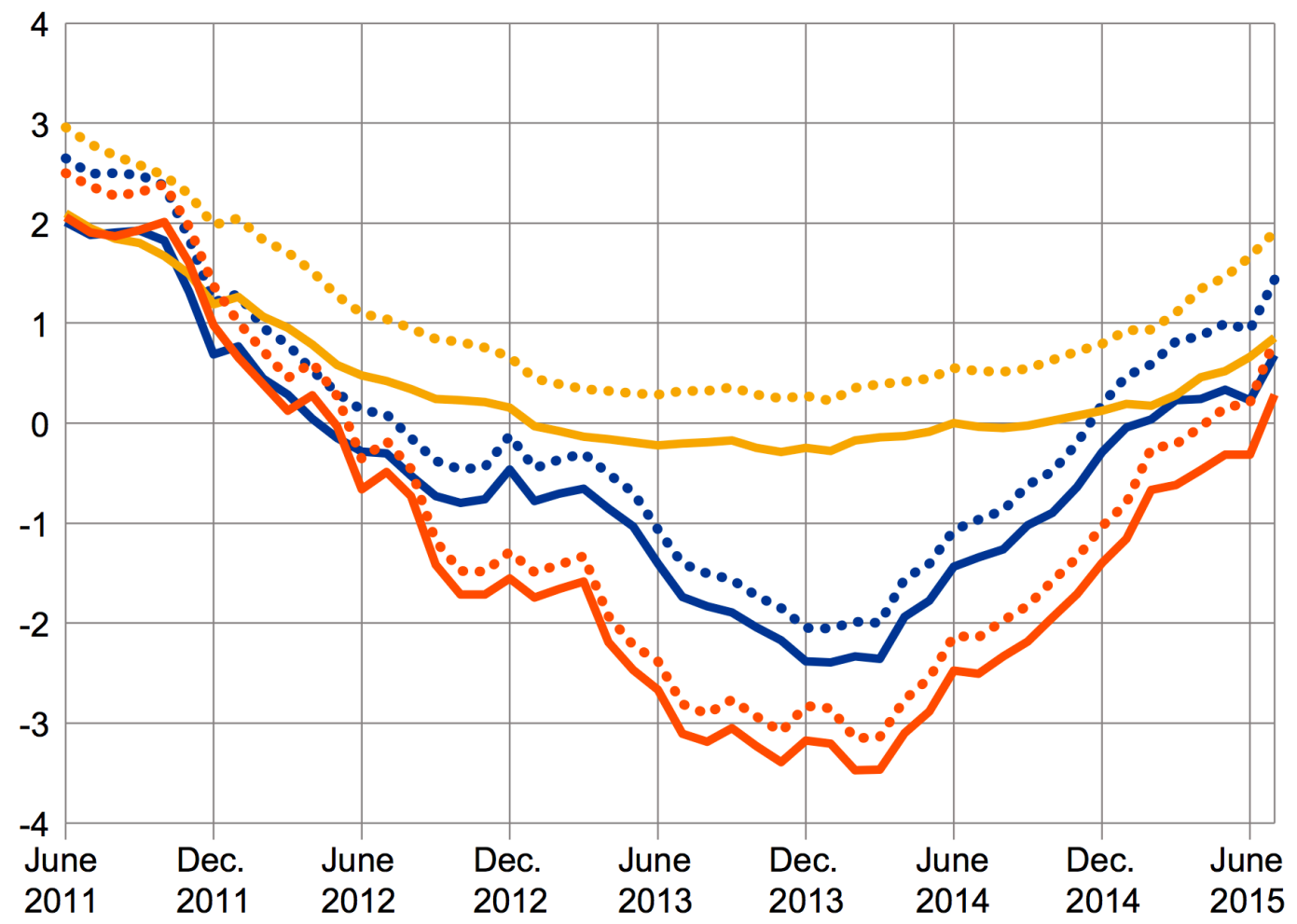

(Source ECB)

\section{Loan rejection figures}

We have just established that, from $2012 \mathrm{Q} 3$ to $2015 \mathrm{Q} 4$ the amount outstanding of loans to NFC has been falling, although business demand was significantly increasing. During that time, loan rejections figures consistently dropped (see figure 6). The only way to account for these statistics and to make them consistent would be that the banks are granting more loans, but constraining more tightly the amount lent per application, so that the global outstanding volume would be stalling. Such rationing behaviour would not allow the businesses to carry on their projects, barring a significant recovery of investment, output and employment. 
Figure 6 - loans rejection evolution

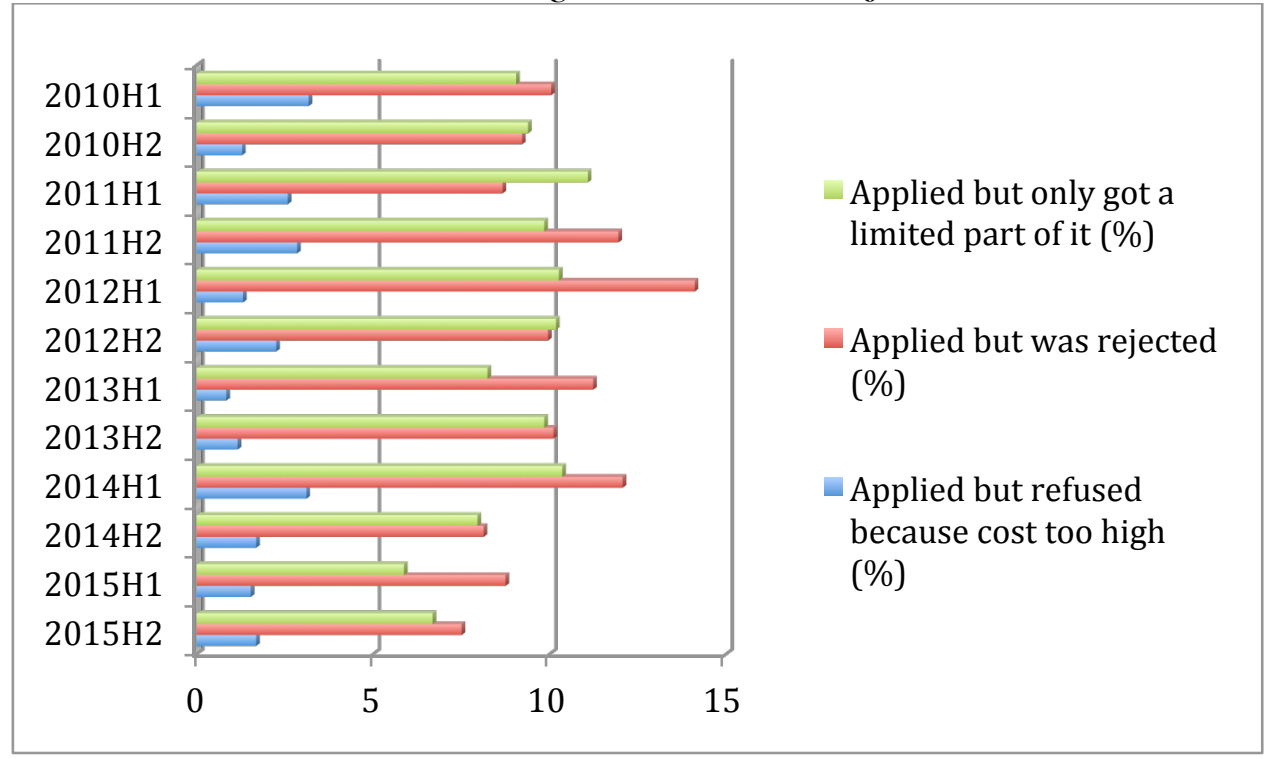

Source: ECB statistical datawarehouse

\section{Bank asset-side unwinding}

It shall be emphasized that, in the Eurozone, the fulfilling of regulatory constraints has not been obtained only by raising the amount of regulatory capital but also by a reduction of the $\mathrm{RWA}$, as figure 7 shows. It is quite likely, then, that in order to save capital, the most impacted assets were those with the higher RWA per $\mathrm{E}$ : corporate loans might hence have been impacted for this reason. While one may think this gives reason to hope this is over now that the banks have enough regulatory capital, one might not forget that I. US leverage rules and 2. EU rules under overhaul (such as credit risk measurement) are likely to induce prudence from the banks. Unless it has been proved, this argument remains theoretical, though.

Figure 7: Evolution of CET1 capital vs RWA over time (for Group 1 banks) under full implementation of CRD IV - CRR.

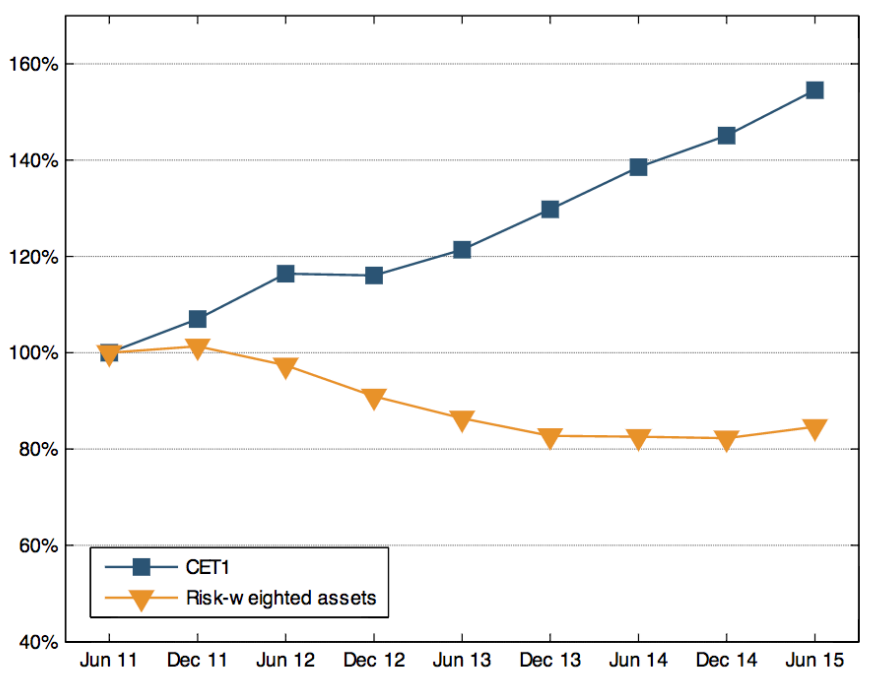




\section{2. theoretical explanations}

In his a chapter of section 2 from this book, Jean-Paul Laurent insisted the quantitative impact studies so far proved to be wrong for three reasons at least: the were done on the basis of pre-reform portfolios likely to be changed once the reform was enacted, then the contribution of banks to impact studies were probably (selection-) biased, eventually the exact rules were not determined, hence the banks' response could not be considered reliable. We would like to stress the later phenomenon.

The mechanism discovered by the risk-taking channel, especially the 'forward guidance channel' is likely to work if it builds up significant inflationary expectations, but every empirical evidence show that it does not work as of spring 20I6. On the contrary, as the amount lent is not picking up, negative expectations are at work on the banks' side. The most likely reason of these negative expectations might be the future evolution of regulation: BCBS 2015 is asking for a revision of the credit risk standard approach measurement, while EBA has launched a regulatory review of the internal rating based approach (EBA 20I6a) which is likely to lead to stiffened risk valuation model, hence increased regulatory capital for credit risk, that is, for corporate loans. There is nothing certain in this process, except that the banks are reacting prudently. Eventually it might happen that the binding constraint be the banks' expectations about future regulation.

Contrary to a widely shared opinion, according to which the banks have lobbyists in Brussels, which allow them to influence the regulator, there are good reasons for banks to be overly risk averse in appraising the future state of regulation since they currently have no power to shape its evolution. We already mentioned that US leverage regulation has an impact on US-listed European banks: here they have no command of a regulatory impact which is quite subtle as the problem is not about the leverage itself, but about how investors would perceive a higher leverage of EU banks. Another very delicate issue at the moment is the competition among authorities: this is the situation where authorities do not coordinate themselves in order to produce aligned incentives. If we take for instance the regulatory capital, then it is clear that the EU rules organised a playing field, which is neither level nor coordinated. Looking back at our table I, one notice that group 2 banks which are not supervised by the SSM have their capital requirements checked (and pillar 2 buffers decided) by their national supervisor and their countercyclical buffer tuned by their nationally competent authority (which is usually not the same as the supervisor). For group 2 banks supervised by the Single Supervisory Mechanism and group I non-globally systemic banks, this SSM (ECB) plays the role of the national supervisor. Eventually, for Group I globally systemic banks (G-SIB), that G-SIB is decided by the FSB. That is to say: these banks depend on national (CCB), European (pillar $2+$ supervision) and global (FSB) regulators, with no one being able to commit to a comprehensive capital level. It seems clear thus that the bank interpret the future decisions of these competing authorities as potentially more damaging if they $\mathrm{I}$. were used to a rather familiar relationship with their formerly unique supervisor, 2. do acquire risky assets such as corporate loans.

The 'risk-taking channel' of monetary policy is just not effective enough as of spring 20I6, while the risk-taking channel of anticipated regulation is probably strengthening 
the bank' overall risk aversion. This is the end of the narrative we sketched so far, let us describe it more completely.

\subsection{A narrative since the crisis}

The following table summarizes the information of this section. The pre-crisis and immediate post-crisis profile led to falling amount of NFC financing as a consequence of the slowdown: while demand has been slowly growing in 2009-2010, the banks have been strongly turning down NFC demand for additional credit as a result of growing risk aversion against crisis (2008), then against possible, plausible and imminent reform: as soon as January 2009, the BCBS offered a consultative document about 'proposed enhancement of to the Basel II framework'; the Basel III package was eventually disclosed in December 20I0, with CRD IV proposed by the European Commission in July of 20II, voted two years later for implementation on July $\mathrm{I}^{\text {st }}$, 20I4. Hence the likelihood of reforms has been increasing since 2009 in a harsh environment, were banks were made responsible for the financial crisis and the subsequent economic misfortunes, and were submitted to a regulatory avalanche that was not built as a consistent project but as a pile of recriminations.

\begin{tabular}{|l|l|l|l|l|l|}
\hline Year & $\begin{array}{l}\text { Banks } \\
\text { RWA }\end{array}$ & $\begin{array}{l}\text { Demand } \\
\text { for loans }\end{array}$ & $\begin{array}{l}\text { NFC loans } \\
\text { outstanding } \\
\text { amount } \\
\text { growth }\end{array}$ & $\begin{array}{l}\text { Constraint } \\
\text { by new } \\
\text { regulation }\end{array}$ & $\begin{array}{l}\text { Constraint } \\
\text { by } \\
\text { anticipated } \\
\text { future } \\
\text { regulation }\end{array}$ \\
\hline 2008 & & Falling & Slowing & No & No \\
\hline 2009 & & Low & Negative & No & Possibly \\
\hline 2010 & & Rising & Negative & No & Possibly \\
\hline 2011 & Rising & Falling & Constant & No & Likely \\
\hline 2012 & Falling & Falling & Negative & No & Likely \\
\hline 2013 & Falling & Rising & Negative & Likely & $\begin{array}{l}\text { Almost } \\
\text { certain }\end{array}$ \\
\hline 2014 & Constant & Rising & Negative & Likely & $\begin{array}{l}\text { Almost } \\
\text { certain }\end{array}$ \\
\hline 2015 & Rising & Rising & Constant & Likely & $\begin{array}{l}\text { Almost } \\
\text { certain }\end{array}$ \\
\hline
\end{tabular}

While demand for loans was clearly depressed in 20I-20I2, it is hard to believe that future reform was playing a definite role in the falling amount of loans. But when demand picked up in 2013, the banks did not follow. As Basel III/CRD was about to be implemented, the banks lowered their RWA to meet the regulatory capital standard, and it is likely that they did this by cutting first the most capital intensive assets, such as corporate loans. The lowering of the interest rate down to zero by the relaxed monetary policy beginning in late 20II was not enough. In 20I4 and 20I5, demand for loans from NFC grew stronger without the effective loans outstanding to rise. It seems that, forward guidance and extreme monetary policy, although they were theoretically justified to deliver a boost to corporate borrowing, could not work as the banks were frightened with projected implementation of further capital buffers to be decided by unpredictable authorities: while the financial macroeconomists were theorizing lowering risk aversion 
through clever monetary policy, banks were experiencing rising uncertainty aversion in front of a regulatory future they could no longer see through or influence.

The remaining questions are whether this state of affairs is going to last, and what can be done to ease up the recovery.

\section{From prevision to recommendations}

Recent initiative by the European Commission give us some insights of what is going to happen in the next few months. (4.I.). Then we offer some recommendations to lead the next steps of banking regulation and business-driven growth (4.2.).

\subsection{Plausible next months}

Loans to NFC are not likely to restart strongly as there is a backlog of troubled assets (non performing loans in Italian banks, for instance), plus uncertain future steps of regulation. Even straightforward incentives such as the SME supporting factor, which amounted to reducing by almost 30\% the capital charges for loans to SME, were not met with any success in 2015 (EBA 20I6b). This might be considered as a sign of extreme uncertainty aversion by the banks.

Fortunately, as EBA 20I6b, the SME supporting factor will continue to incentivize lending to SME in the near future, and it will be subjected to further close monitoring. That will enable to track as early as possible either the furthering of uncertainty aversion or the shift to a lesser risk-averse bank asset choice policy. It is not unlikely that further regulatory evolution will be necessary to trigger this latter move.

\subsection{Tuning regulation to trigger growth}

If we have been correct in diagnosing that the binding factor of corporate lending was anticipated regulation by banks, then it seems crucial to address that particular source of bank uncertainty aversion. We have identified competition among authorities as a possible source of uncertainty aversion, this concept being effective both at the legal and supervisory level. In order to ease up this concern, it might be fruitful to move toward a more consistent design and implementation of the regulatory package. A pause for assessment of the existing reforms, as asked for by the European Parliament, seems reasonable.

As we have show, regulatory capital is a example of potential competition among authorities, as we have shown it was decided by up to three different authorities at three different levels without any consistency checks. Moving away from the coordination issues implied by competition among authorities would imply aligning the role of stakeholders: this could be achieved only via a consistent regulatory framework. One could think basically that the supervisor should check the compliance of capital requirements and internal models with regulations; while a banking authority could design the models to measure the risks experienced by the banks. Eventually, the acceptable level of risk with every institution (i.e. microprudential) must be decided by the law, while the systemic risk policy might be taken care of by a higher level authority, either purposive or political, which would set up dedicated capital pockets to address 
designated risks, the breakdown among banking institutions would be made according to risk measures provided by models designed by the banking authority.

In this "pyramidal" model (supreme macroprudential authority deciding "risk budgets", banking authority designing risk measurement models, supervisor verifying that they are correctly implemented into banks) there seem to be no conflict among authority... but possible agency conflicts: these might be addressed through classical incentives. At least, the signal to banks would be clear and reliable, excluding uncertainty aversion. Macron 2016 made a very clear point about such risk budgets. Rodarie 2015 has shown that if implemented correctly, they would require the political leaders to take full responsibility for their choices. While this would mean a deep change of the principles of overall regulatory architecture, with a long time to go, it is possible to advance in the meantime.

In the meantime, the broken up piping of corporate financing might be fixed by using different vehicles. For instance, securitization might help either direct funding of middle-market companies through CLO or indirect funding of SME by securitizing other credits (RMBS for instance) thus freeing up regulatory capital to grant new SME loans. A more precise review of the options offered by securitization appears in the companion chapter by Daphné Héant et alii. It is up to the member states to develop their financial ecosystem, as it has been the case in the very last months: Renzi has developed private equity (Politi 2or6) in Italy, while in France, the projected loi Sapin 2 in its art. 33 is allowing to life insurance companies to shift investments to purposely set up pension funds in order to switch from solvency 2 to solvency i regulatory regime. The implied regulatory capital relaxation would make it easier to invest in stocks or other corporate liabilities, which are too heavily charged under S2. Schackmann-Fallis and Weiss (2014) are advocating that banks are providing the businesses with stable and reliable funding, which should not be substituted by tempting new gadgets; it is clear that with overly regulated banks, any opportunity might be overexploited by the shadow banking system. Hence the need for consistency among stakeholders.

\section{Conclusion}

The European Union, which was not the origin of the financial crisis, has almost lost a growth cycle to the US. Our analysis has shown that the negative effect of the Basel III package expected by the pre-QE studies are almost annihilated today. The recession must then have other causes: falling corporate lending volumes resulted from falling demand in the aftermath of the financial crisis, but this is longer the case. The EU is trying to incentivize corporate lending, via forward guidance as well as 'supporting factor' cutting down the Basel capital requirements. The macroeconomic theorists are trying to account for future success of monetary policy around zero nominal interest rate via the risk-taking channel. All these clever initiative failed to deliver. As a consequence, we might infer that banks are simply not taking any risks: rather than appealing to risk aversion, we would like to argue that the banks seem especially embarrassed by future regulatory developments, which appear remote and uncertain. The binding constraint for corporate lending and growth in the EU is then plausibly a combination of banks' expectations of future regulation and strong uncertainty aversion. While we offer some mitigation prospects, see 4.2., we hope that the theoretical developments of the recent years will quickly yield both theoretical advances and practical results. 


\section{References}

Antipa P. Matheron J. 20I4. Interactions between monetary and macroprudential policies. Financial Stability Review, i8, 225-239.

Brundsen J. 2015. "European Commission changes tone over financial regulation", Financial Times, October I.

BCBS. 20I4. Basel III: the net stable funding ratio. Available on: http://www.bis.org/bcbs/publ/d295.pdf

BCBS. 2015. Second Consultative Document Standards Revisions to the Standardised Approach for credit risk. December 2015. Available on: http://www.bis.org/bcbs/publ/d347.pdf

DG FISMA 20ı5a Consultation document

DG FISMA 20I5̆b Annex to the consultation document

EBA. 20I4. Second report on impact assessment for liquidity measures under Article $509(\mathrm{I})$ of the CRR. Available on: https:/www.eba.europa.eu/regulation-andpolicy/liquidity-risk

EBA. 20I5. EBA Report On Net Stable Funding Requirements under Article 5ıo of the CRR. EBA/Op/20I5/22.

EBA. 20r6a. Opinion of the European Banking Authority on the implementation of the regulatory review of the IRB Approach. EBA/Op/20I6/or.

EBA. 2or6b. EBA Report on SMEs and SME Supporting Factor. EBA/OP/20r6/o4. Available from: https:/www.eba.europa.eu/-/eba-publishes-the-report-on-smes-and-thesme-supporting-factor

EC 2013. Capital Requirements - CRD IV/CRR - Frequently Asked Questions. EC

MEMO I3/69o. http://europa.eu/rapid/press-release_MEMO-ı3-69o_fr.htm

ECB. 20I5. The transmission of the ECB's recent non-standard monetary policy measures. ECB economic Bulletin, 20ı5/7, 32-5г.

EP 20ı6. European Parliament resolution of ı9 January 2016 on stocktaking and challenges of the EU Financial Services Regulation: impact and the way forward towards a more efficient and effective EU framework for Financial Regulation and a Capital Markets Union, P8_TA(20I6)ooo6.

Hale T. 2oi6. "Italian banks extend gains on rescue fund hopes", Financial Times, April II.

Institute of International Finance (2010), Interim Report on the Cumulative Impact on the Global Economy of Proposed Changes in the Banking Regulatory Framework. Online.

Institute of International Finance (20II), The Cumulative Impact on the Global Economy of Changes in the Financial Regulatory Framework. Online.

JC. 2or6. Joint Committee Report on Risks and Vulnerabilities in the EU Financial System. JC 20i6 I7.

Macron E. 20ı6. Interview. Risques, ı05, II.

Pigou, A. C. I943. The Classical Stationary State. Economic Journal 53, 343-35ı. doi:I0.2307/2226394.

Politi J. 20ı6. Private equity fights Italy tax changes. Financial Times. June I2. 
Sanderson R. 2016 Corporate Italy risks 'asphyxia', warns business chief. Financial Times. March ı6, 2016 8:ı7 am

Schackmann-Fallis K.-P., Weiss M. 2014. Régulation des marchés financiers et financement des entreprises. Revue d'économie financière, 2, 209-232.

Wise P. 2or6. "Court blocks Novo Banco bond move", Financial Times, April 29. 